\title{
Corporate Governance, Financial Characteristics, Macroeconomic Factors and Performance of Commercial and Service Firms Listed at the Nairobi Securities Exchange
}

\author{
Moses Odhiambo Aluoch \\ Prof. Erasmus S. Kaijage \\ Dr. Cyrus M. Iraya \\ Department of Finance and Accounting \\ School of Business \\ University of Nairobi, Kenya \\ Prof. Martin Ogutu \\ Department of Business Administration \\ School of Business \\ University of Nairobi, Kenya
}

\begin{abstract}
The study examined relationships among corporate governance, financial characteristics, macroeconomic factors and performance of Commercial and Service firms listed at the Nairobi Securities Exchange. The specific objectives were to establish the effect of corporate governance on performance of Commercial and Service firms listed at the Nairobi Securities Exchange and to determine the intervening effect of financial characteristics on corporate governance and performance of Commercial \& Service firms and to establish the moderating effect of corporate governance and performance of firms. This study was anchored on wealth maximization theory, agency theory and positivism philosophy. The study used census approach and a target population of 10 Commercial \& Service firms listed at the Nairobi Securities Exchange between 2002 and 2016 were incorporated. The study used panel data and employed longitudinal descriptive research design to determine relationships amongst study variables. A panel data regression analysis was conducted using random effects model which allowed the companies to have a common mean value of the intercept to determine whether corporate governance influences performance of Commercial \& Service firms. The research findings revealed that Liquidity and Interest rate significantly affect Return on Assets while Corporate Governance, Investments, Leverage, Growth Domestic Product Growth rate and Inflation rate had an insignificant effect on Return on Assets of listed commercial service firms. The results further revealed that only firm 's Investments were significantly related to Tobin's $Q$ of listed commercial \& service firms in Kenya. Corporate Governance, Leverage, Liquidity, Growth Domestic Product Growth rate, Interest rate and Inflation rate were found to have insignificant effects on Tobin's $Q$ of listed commercial \& service firms. The study also concluded that commercial and service listed firms in Kenya continued to record poor performance despite corporate governance practices. The shareholders of commercial and service listed firms may adopt the findings of this study to restructure their corporate governance policies and practices to improve performance of their firms.
\end{abstract}

Keywords: Firm performance, Macroeconomic Factors, Corporate Governance, Financial Characteristics, Commercial \& Services

\subsection{Introduction}

\section{Background Information}

Performance of commercial and service firms listed at Nairobi Securities Exchange has varied since the introduction of corporate governance policies and practices by Capital Markets Authority of Kenya in the year 2002. Corporate governance policies and practices used in this study include board structure and board activities. The board structure include: board composition which comprises both executive and non-executive directors, gender and ethnicity (Carter, Simkins, \& Simpson, 2003); board skills and experience, are occupational expertise of board members (Kesner,1998); board age, is the average age of board members (Rose, 2007); and board size, is the number of directors instituting the board (Jensen, 1993; Khanchel, 2007). The board activities are responsibilities performed by the board and committees set up by board for specific duties. 
The board activities include board tenure which is the duration the directors take in a firm (Mathew, Paul, Kamel \& Cherif, 2010); board ownership which is the holdings in a firm's stock by board members (Brickley, Lease \& Smith, 1988); board tools which are necessary tools and aids in place to enable discharging of responsibilities of the board (CMA, 2015); board meetings including statutory and non-statutory meetings (Lipton \& Lorch, 1992) and board committees for deliberations of board activities (Klein, 2002). Board compensation is the remuneration to board members (Murphy, 1984).

The financial characteristics used in this study were: investment, leverage and liquidity because of their direct influence to firm performance. Investment refers to the sacrifice of current cash flows for future cash flows. It involves time, risk and returns since the sacrifice takes place in the present, and is certain, while returns come later, and are uncertain (Sharp et al., 2005). Investment in tangible and intangible assets such as property, plant, equipment and securities ensures a good firm's performance in profitability and value (Mudida \& Ngene, 2010). Investment measures the increase in capital spending such as buying new machines, building bigger factories. Investment in long term assets makes firms to remain competitive and to survive given constant flow of ideas for new products, making existing products better and reducing the operating cost (Hillie, Jaffe, Jordan, Ross \&Westerfield, 2010). The overall investment of a nation is a component of aggregate demand and therefore boosts economic growth. Effective investment should also increase the productivity capacity of the economy and firms. Investment in new technology and capital goods can increase the productivity capacity of the economy leading to an increase in the long run trend rate of economic growth. Investment also increases the competiveness of an economy (Koori, 2015). Liquidity plays a significant role in determining success or failure of a firm. It affects business performance due to its effect on the firm's profitability and value (Vahid, Mohsen \& Mohammadreza, 2012). Liquidity is one of the pillars of performance of firms. Firms must have an optimal level of liquidity in order to maximize their performance. Large inventories and generous trade credit policy may lead to higher sales. Firms with larger stock tend to reduce the risk of stock-out, and also a good trade credit policy may stimulate sales because it allows customers to assess quality before paying (Deloof, 2003).

Gross Domestic Product (GDP) is a measure for all finished goods and services produced in a country for a specific fiscal year. GDP is equal to total investment, consumption, government spending, and exports less value of imports (Maclennan\& Pryce, 1996). The real GDP portrays economic performance in a country. Interest rate is a price that relates to present claims on resources relative to future claims on resources. It is the price that a borrower pays in order to be able to consume resources now. It represents the cost of borrowing capital for a given period of time. It also represents the price the firms pay for use of debt capital. It is the fee paid for the use of borrowed assets. Inflation is general rise in price levels for a basket of products (Gallagher, 2011). Inflation refers to the change in the general level of prices in the economy over a given period of time (Santoni, 1986). Inflation rates have effects on the value of money and it is measured by the changes in the consumer price index (Liow, Ibrahim \& Huang, 2005).

Performance of a firm is a measure of overall well-being of a firm in terms of wealth creation over a given period of time. It measures how a firm can use investment in long and short term assets to create revenues (Iraya, 2014). Measures of firm performance can be achieved using either accounting or market metrics with different theoretical foundation (Hillman \& Keim, 2001). This study used Return on Assets and Tobin's' Q for both accounting and market metrics respectively. Nairobi Stock Exchange, (NSE) is the principal bourse in Kenya offering automated platform for the listing and trading in multiple securities. The market has an obligation to guarantee effective trading in securities and derivatives and enhances economic development. NSE is publicly traded and the second self-listed exchange in Africa (NSE, 2016). As at December 2016, there were sixty five (65) firms listed at the NSE. The Firms were grouped into twelve different sectors including agricultural, automobiles and accessories, banking, commercial and services, construction and allied, energy and petroleum, insurance, investment, investment services, manufacturing and allied, telecommunication and technology and real estate investment trust.

Contentious proposals by many researchers on the relationship between corporate governance and firm performance remained unsettled for a long time. Great corporate failures around the world in recent years have complicated the problem. Most studies have been carried to examine the relationship between corporate governance and firm performance and the outcomes have remained conflicting. Some studies established positive significant relationship between corporate governance and firm performance (Van-Ness et al., 2010; Mulili \& Wong, 2011, Rambo, 2013; Okiaga, 2013; Gachoki \& Rotich, 2013; Aduda et al., 2013; Lakaram, 2014; Wang, 2014; Badriyah et al., 2015; Ahmed \& Hamdan,2015; Michelberger,2017; Ibe, Ugwuanyi \& Okanya, 2017). Other studies did not establish any significant relationship between corporate governance and firm performance (Nandi \& Ghose, 2012; Waweru \& Riro, 2013; Vo\& Nguyen, 2014; Jacob, 2015, Faizul \&Thankom, 2016; Souha \& Anis. 2016; Buvanendra, Sridharan \& Thiyagarajan, 2017). 


\subsection{Literature Review}

\subsubsection{Theoretical Review}

\section{Wealth Maximization Theory}

Wealth maximization theory was developed by Ponser (1983). According to the proponents of this theory, the immediate operating goal and the ultimate purpose of all public corporations is and should be to maximize return on equity capital. Windsor and Boatright (2010) as proponents of shareholder's wealth maximization argue that the theory focuses on the motives and behaviors of financial stakeholders. Wealth maximization theory has received criticism from various authors. Majority of the critics argue that if the wealth of a firm is maximized, it would be of benefit to both debenture holders and preference shareholders too. Directors act as agents of shareholders; however there is always conflict of interest between directors and shareholders. Jones and Felps (2013) also posit that no extent scholarship has systematically analyzed the utilitarian foundations of shareholder's wealth maximization.

\section{Stewardship Theory}

Stewardship theory was developed by Donaldson and Davis (1991). The theory was an innovative view in understanding relationship between ownership and management of a firm. Directors are stewards making decisions for long term survival of firms as well as maximizing shareholders' wealth. Directors normally perceive firms as extension of themselves, rather than use their resources for their own interest; the directors' main interest is ensuring the sustained life and success of the firm. The theory is based on the duties of directors as stewards, integrating their goals as part of the firm and recognizing the importance of structures that empower the steward and offers maximum autonomy built on trust (Donaldson \& Davis, 1991). The critics of stewardship theory argue that there is lack of conclusive evidence linking board to firm performance which has turned researchers' attention back to the black box of board process, and emphasized the element of firm context in determining the role and value of the corporate governance (Huse, 2003). This implies that board of directors which are components of corporate governance may act as stewards but they do not have direct impact on firm profitability.

\section{Resource Dependency Theory}

Resource dependency theory was developed by Pfeffer and Salancik (1978). The theory deals with the study of how external resources affect the behavior of the organization. The procurement of external resources is an important tenet for both the strategic and tactical management of any company. The theory concentrates on the role of board of directors in providing access to resources needed by the firm. The theory emphases on the activities that directors play in finding resources required by the firm through connections to its external environment (Hillman, Canella \& Paetzold, 2000). The theory further gives direction on recruitment of directors who assist in gaining access to vital resources of the company for survival (Johnson, Daily \& Ellstrand, 1996). The critics of this theory have based their arguments concerning the boundary of space; Casciaro and Piskorski (2005) for instance argue that the Resource dependency theory can be bounded to the boundaries of the organization concerning internal issues. Hillman et al., (2000) on the other hand, posit that the Resource dependency theory is bounded to the environment of the organization and assumes that the organizational actions are constrained to the events in the organizational environment, leaving the environment as a space boundary.

\subsubsection{Empirical Review}

Michelberger (2017)found that German corporate governance compliance reports remained stable in five year period 2010-2014, none of the styles of governance factors showed a higher and significant correlation with firm performance indicators of revenue growth, profitability and total shareholder's return, most corporate governance variables had positive effect on the total shareholder's return, executive board and supervisory board compensations have only very low effect on revenue growth and profitability. Ibe, Ugwuanyi and Okanya (2017) found that board size and executive directors' remunerations have negative and significant effect on firm performance (ROA), while board independence and institutional ownership indicated positive and significant impact on the financial performance.

Faizul and Thankom (2016) found statistically significant positive relationship between a firm's corporate governance quality and its valuation; and there was no statistical relationship between corporate governance and operating performance. Lekaram (2014) established that the board size is positively and significantly related to performance of manufacturing firms listed in Kenya and a large proportion of external directors lead to a higher shareholders' value. The study did not consider all the firms, making inference of the results is difficult to a wider population and used only two variables of corporate governance which is inadequate for drawing a broader conclusion. This study employed more characteristics of corporate governance and considered all commercial and service firms listed at the NSE. 
Rambo (2013) found that boards of listed and non-listed companies are significantly different and there is a need of legal framework to align CMA guidelines to protect investors. This study included commercial and service firms listed at the NSE.

\subsection{Research Methodology}

This study used a census approach and a target population of the study comprised all commercial and service firms listed at the NSE between years 2002 and 2016. A total of ten commercial and service companies were listed at the NSE as at $31^{\text {st }}$ December 2016. Companies listed at NSE were targeted because the NSE acts as a country's financial barometer and the market had received empirical studies and financial data that were used to support this study (Ongore $\&$ K'obonyo, 2011). The 10 companies were screened against various factors which included availability of data for the period under review and the integrity of data. Data was extracted from annual reports of listed firms from CMA; published financial statements from NSE; and economic reports from Central Bank of Kenya (CBK) and Kenya National Bureau of Statistics (KNBS). This study used descriptive analysis and panel data regression in analyzing the relationship between corporate governance and performance of commercial and service firms listed at the NSE.

Descriptive analysis was carried out to measure dispersion of variables such as standard deviations and coefficient of variation which was used to disclose the volatility in relationships of the variables under study. A panel data regression analysis was conducted using random effects model which allowed the companies to have a common mean value of the intercept to determine whether corporate governance influence performance of commercial and service firms. Coefficient of Determination $\left(\mathrm{R}^{2}\right)$ and p-values were used to interpret the regression functions at a level of significance of 0.05 (Bryman \& Cramer, 1997). The respective individual regression coefficients were also tested for their statistical significance using the t-test. Simple regression model was used to test hypothesis one: Relationship between Corporate Governance (CG) and Performance of Firms (FP). Panel data regression model of random effects was used to determine the relationship among Corporate Governance (CG), Financial Characteristics (FC), Macroeconomic Factors (MF) and Performance of Firms (FP). These models were used to test hypothesis four, the joint effect:

$\mathrm{FP}_{\text {it }}=\beta_{0}+\beta_{1} \mathrm{CG}_{\mathrm{it}}+\beta_{2} \mathrm{FC}_{\mathrm{it}-1}+\beta_{3} \mathrm{MF}_{\mathrm{it}-1}+\mathrm{c}_{\mathrm{i}}+\dot{\varepsilon}_{\mathrm{it}}$

Where:

$\mathrm{FP}_{\mathrm{ij}}$ is Performance of Firms;

$\mathrm{CG}$ is Corporate Governance;

FC is Financial Characteristics;

MF is Macroeconomic Factors;

$c_{i}$ unobserved variable; $\beta_{0}$ is the intercept;

$\beta_{1}, \beta_{2}, \beta_{3}, \beta_{4}$ and $\beta_{5}$ are regression coefficients for Corporate Governance, Financial Characteristics and Macroeconomic Factors for firm $\mathrm{i}$ in time $\mathrm{t}$

$\dot{\varepsilon}$ is error term. The study Null hypotheses were rejected when calculated p-values exceeded 0.05 significance level adopted by the study.

\subsection{Results and Discussions}

\subsection{Descriptive Statistics of Study Variables}

Table 1 shows the descriptive statistics of the variables under study. The results show the mean standard deviation, minimum, maximum of corporate governance variables, financial characteristics variables, macroeconomic factors and financial performance variables of listed firms in commercial and services sector in Kenya. 
Table 1: Descriptive Statistics of Study Variables

\begin{tabular}{llllll}
\hline Variable & $\mathrm{N}$ & Mean & Std. Dev. & Min & Max \\
\hline Board Independence & 101 & 0.75 & 0.15 & 0.38 & 0.94 \\
Gender Diversity & 101 & 0.20 & 0.26 & 0.00 & 1.00 \\
Occupational Expertise & 101 & 6.45 & 2.89 & 2.00 & 15.00 \\
Board Age & 101 & 55.72 & 4.05 & 47.75 & 63.50 \\
Board Size & 101 & 9.00 & 3.06 & 4.00 & 16.00 \\
Board Tenure & 101 & 3.74 & 0.89 & 3.00 & 5.00 \\
Board Ownership & 101 & 0.11 & 0.14 & 0.00 & 0.66 \\
Board Tools & 101 & 2.54 & 0.59 & 1.00 & 4.00 \\
Board Meeting & 101 & 4.62 & 1.08 & 3.00 & 8.00 \\
Number in Board Committees & 101 & 3.04 & 1.09 & 1.00 & 6.00 \\
Committees Meeting & 101 & 10.70 & 5.69 & 2.00 & 24.00 \\
Board Remuneration & 101 & -0.03 & -1.11 & 10.6 & 0.7 \\
Investments & 101 & 0.57 & 0.24 & 0.0 & 0.9 \\
Leverage & 101 & 0.82 & 3.11 & -7.08 & 0.03 \\
Liquidity & 101 & 0.04 & -0.31 & 1.28 & 0.72 \\
GDP Growth Rate & 120 & 4.85 & 2.19 & 0.20 & 8.40 \\
Interest Rate & 120 & 15.07 & 2.26 & 12.25 & 9.85 \\
Inflation Rate & 120 & 7.43 & 3.50 & 0.90 & 15.20 \\
ROA & 101 & 0.11 & 0.34 & -1.38 & 0.67 \\
Tobin's Q & 101 & 1.77 & 1.05 & 0.74 & 0.59 \\
\hline
\end{tabular}

\subsection{Correlation Analysis}

4.2.1 Board Structure and Financial Characteristics in Commercial and Service Firms.

Table 2 presents the correlation findings of board structure indicators and financial characteristics of commercial and service firms listed at NSE. The findings showed that board independence had a positive correlation with investments and liquidity while it had a negative correlation with leverage. Gender diversity had a positive correlation with investments and leverage while it had a negative correlation with liquidity. Occupational expertise had a positive correlation with leverage and liquidity while negative correlation with investments. Board age had positive correlation with investments and leverage while it had negative correlation with liquidity. Finally, the findings showed that board size had positive correlation with leverage and liquidity while it had negative correlation with investments of commercial and service firms listed at NSE.

Table 2: Board Structure and Financial Characteristics in Commercial and Service Firms

\begin{tabular}{|c|c|c|c|c|c|c|c|c|c|}
\hline & & $\begin{array}{l}\text { Board } \\
\text { independence }\end{array}$ & $\begin{array}{l}\text { Gender } \\
\text { Diversity }\end{array}$ & $\begin{array}{l}\text { Occupational } \\
\text { Expertise }\end{array}$ & $\begin{array}{l}\text { Board } \\
\text { Age }\end{array}$ & $\begin{array}{l}\text { Board } \\
\text { Size }\end{array}$ & $\begin{array}{l}\text { Investme } \\
\text { nts }\end{array}$ & $\begin{array}{l}\text { Levera } \\
\text { ge }\end{array}$ & $\begin{array}{l}\text { Liqui } \\
\text { dity }\end{array}$ \\
\hline Board independence & $\mathrm{r}$ & 1 & & & & & & & \\
\hline $\begin{array}{l}\text { Gender Diversity } \\
\text { Occupational }\end{array}$ & $\mathrm{r}$ & $-.251 *$ & 1 & & & & & & \\
\hline Expertise & $\mathrm{r}$ & $.593 * *$ & $-.359 * *$ & 1 & & & & & \\
\hline Board Age & $\mathrm{r}$ & $.570 * *$ & -0.006 & $.321 * *$ & 1 & & & & \\
\hline Board Size & $\mathrm{r}$ & $.720 * *$ & $-.483^{* *}$ & $.913 * *$ & $.407 * *$ & 1 & & & \\
\hline Investments & $\mathrm{r}$ & 0.01 & $.301 * *$ & -0.066 & $.473^{* *}$ & -0.230 & 1 & & \\
\hline Leverage & $\mathrm{r}$ & -0.003 & 0.086 & 0.106 & 0.040 & 0.020 & 0.153 & 1 & \\
\hline Liquidity & $\mathrm{r}$ & 0.099 & $-.429 * *$ & $.271 * *$ & -0.178 & $0.199 *$ & $-.649 * *$ & -0.09 & 1 \\
\hline
\end{tabular}

** Correlation is significant at the 0.01 level (2-tailed). 


\subsubsection{Board Activities and Financial Characteristics in Commercial and Service Firms}

Table 3 presents the findings on correlation analysis between board activities indicators and financial characteristics (investments, leverage and liquidity) in listed commercial and service firms. The findings showed that board tenure had a positive correlation with investments while it had a negative correlation with liquidity and leverage. Board ownership had positive correlation with liquidity and leverage while it had negative correlation with investments. The findings also showed that board tools were negatively correlated with investment and positively correlated with leverage and liquidity. Board meetings had positive correlation with leverage and investments and a negative correlation with liquidity. The findings further showed that number in board committees was positively correlated with liquidity while negatively correlated with investment and leverage. Board committee meetings on the other hand were positively correlated with liquidity and negatively correlated with investments and leverage. Board remuneration had a positive correlation with liquidity and negatively correlated with leverage and investments of listed commercial and service firms in Kenya.

Table 3: Board Activities and Financial Characteristics in Commercial and Service Firms

\begin{tabular}{|c|c|c|c|c|c|c|c|c|c|c|c|}
\hline & & $\begin{array}{l}\text { Board } \\
\text { Tenure }\end{array}$ & $\begin{array}{l}\text { Board } \\
\text { Ownership }\end{array}$ & $\begin{array}{l}\text { Board } \\
\text { Tools }\end{array}$ & $\begin{array}{l}\text { Board } \\
\text { Meetings }\end{array}$ & $\begin{array}{l}\text { No.in } \\
\text { Board } \\
\text { Committ } \\
\text { ees }\end{array}$ & $\begin{array}{l}\text { Committe } \\
\text { es } \\
\text { Meetings }\end{array}$ & $\begin{array}{l}\text { Board } \\
\text { Remuner } \\
\text { ation }\end{array}$ & Investments & Leverage & Liquidity \\
\hline $\begin{array}{l}\text { Board Tenure } \\
\text { Board } \\
\text { Ownership }\end{array}$ & $\mathrm{r}$ & $-.625 * *$ & 1 & & & & & & & & \\
\hline $\begin{array}{l}\text { Board Tools } \\
\text { Board }\end{array}$ & $\mathrm{r}$ & -0.111 & $.202 *$ & 1 & & & & & & & \\
\hline $\begin{array}{l}\text { Meetings } \\
\text { No. in Board }\end{array}$ & $\mathrm{r}$ & $-.288 * *$ & $.409 * *$ & -0.098 & 1 & & & & & & \\
\hline $\begin{array}{l}\text { Committees } \\
\text { Committee }\end{array}$ & $\mathrm{r}$ & $-.289 * *$ & -0.073 & -0.034 & $-.216^{*}$ & 1 & & & & & \\
\hline $\begin{array}{l}\text { Meetings } \\
\text { Board }\end{array}$ & $\mathrm{r}$ & 0.081 & -0.114 & -0.121 & -0.15 & $.748 * *$ & 1 & & & & \\
\hline Remuneration & $\mathrm{r}$ & -0.111 & 0.052 & 0.153 & 0.04 & -0.123 & $-.284 * *$ & 1 & & & \\
\hline Investments & $\mathrm{r}$ & $.378 * *$ & $-.298 * *$ & $-.349 * *$ & $.199 *$ & $-.317 * *$ & -0.012 & -0.131 & 1 & & \\
\hline Leverage & $\mathrm{r}$ & -0.035 & 0.122 & 0.03 & 0.01 & -0.05 & -0.003 & -0.019 & 0.153 & 1 & \\
\hline Liquidity & $\mathrm{r}$ & $-.211 *$ & 0.01 & $.445 * *$ & $-.400 * *$ & $.305^{* *}$ & 0.091 & 0.084 & $-.649 * *$ & -0.097 & 1 \\
\hline & $\mathrm{N}$ & 101 & 101 & 101 & 101 & 101 & 101 & 101 & 101 & 101 & 101 \\
\hline
\end{tabular}

* Correlation is significant at the 0.05 level (2-tailed).

\subsubsection{Board Structure and Macroeconomic Factors in Commercial and Service Firms}

Table 4 presents the results for board structure indicators and macroeconomic factors for listed firms in commercial and service sector in Kenya. The finding presented showed that GDP growth rate had a positive correlation with board independence, gender diversity, board age and board size while it had a negative correlation with occupational expertise. The findings further showed that interest rate was positively correlated with all the board structure indicators. Inflation rate on the other hand, had a negative correlation with board independence, occupational expertise, board size and gender diversity while it was negatively correlated with board age for listed commercial and service firms in Kenya.

Table 4: Board Structures and Macroeconomic Variables in Commercial and Service Firms

\begin{tabular}{lllllll}
\hline & Board & & Occupatio & & & \\
independe & Gender & nal & & Board & & \\
nce & Diversity & Expertise & Board Age & Size & GDP & Interest Rate \\
\hline
\end{tabular}

Board

independence $\quad r \quad 1$

Gender

Diversity $\quad$ r $\quad-.251 * \quad 1$ 
Occupational

$\begin{array}{lllll}\text { Expertise } & \mathrm{r} & .593 * * & -.359 * * & 1\end{array}$

$\begin{array}{lllll}\text { Board Age } & \mathrm{r} & .570 * * & -0.006 & .321 * *\end{array}$

$\begin{array}{lllllll}\text { Board Size } & \mathrm{r} & .720 * * & -.483 * * & .913 * * & .407 * * & 1\end{array}$

$\begin{array}{llllllll}\text { GDP } & \mathrm{r} & 0.127 & 0.029 & -0.01 & 0.134 & 0.01 & 1\end{array}$

Interest Rate

r $\quad 0.099 \quad 0.091$

0.012

0.083

0.02

$-0.151$

Inflation Rate

r $\quad-0.052$

$-0.004$

$-0.001$

0.112

$-0.01$

$-.262 * *$

1

N 101

101

101

101

101

101

$-0.126$

1

** Correlation is significant at the 0.01 level (2-tailed).

\subsubsection{Board Activities and Macroeconomic Variables in Commercial and Service Firms}

Table 5 presents the findings of correlation analysis between board activities indicators and macroeconomic variables among commercial and service firms listed at NSE. The findings similarly showed that GDP growth rate, interest rats and inflation rate had weak association with board activities indicators for listed commercial and service firms in Kenya.

Table 5: Board Activities and Macroeconomic Variables in Commercial and Services Firms

\begin{tabular}{|c|c|c|c|c|c|c|c|c|c|c|c|}
\hline & & $\begin{array}{l}\text { Board } \\
\text { Tenure }\end{array}$ & $\begin{array}{l}\text { Board } \\
\text { Ownership }\end{array}$ & $\begin{array}{l}\text { Board } \\
\text { Tools } \\
\end{array}$ & $\begin{array}{l}\text { Board } \\
\text { Meetings }\end{array}$ & $\begin{array}{l}\text { No Board } \\
\text { Committees }\end{array}$ & $\begin{array}{l}\text { Committees } \\
\text { Meetings }\end{array}$ & $\begin{array}{l}\text { Board } \\
\text { Remu } \\
\text { nerati } \\
\text { on }\end{array}$ & $\begin{array}{l}\text { GDP } \\
\text { Growth }\end{array}$ & $\begin{array}{l}\text { Interest } \\
\text { Rate }\end{array}$ & $\begin{array}{l}\text { Inflati } \\
\text { on } \\
\text { Rate } \\
\end{array}$ \\
\hline $\begin{array}{l}\text { Board Tenure } \\
\text { Board } \\
\text { Ownership }\end{array}$ & $\mathrm{r}$ & $\begin{array}{l}1 \\
-.625 * *\end{array}$ & 1 & & & & & & & & \\
\hline $\begin{array}{l}\text { Board Tools } \\
\text { Board }\end{array}$ & $\mathrm{r}$ & -0.111 & $.202 *$ & 1 & & & & & & & \\
\hline $\begin{array}{l}\text { Meetings } \\
\text { No. of Board }\end{array}$ & $\mathrm{r}$ & $-.288 * *$ & $.409 * *$ & -0.098 & 1 & & & & & & \\
\hline $\begin{array}{l}\text { Committees } \\
\text { Committee }\end{array}$ & $\mathrm{r}$ & $-.289 * *$ & -0.073 & -0.034 & $-.216^{*}$ & 1 & & & & & \\
\hline $\begin{array}{l}\text { Meetings } \\
\text { Board }\end{array}$ & $\mathrm{r}$ & 0.081 & -0.114 & -0.121 & -0.151 & $.748 * *$ & 1 & & & & \\
\hline $\begin{array}{l}\text { Remuneration } \\
\text { GDP Growth }\end{array}$ & $\mathrm{r}$ & -0.111 & 0.052 & 0.153 & 0.04 & -0.123 & $-.284 * *$ & 1 & & & \\
\hline Rate & $\mathrm{r}$ & -0.029 & 0.066 & $.200 *$ & 0.016 & 0.059 & 0.06 & -0.083 & 1 & & \\
\hline Interest Rate & $\mathrm{r}$ & -0.072 & 0.175 & 0.08 & -0.024 & 0.039 & 0.04 & -0.119 & -0.151 & 1 & \\
\hline Inflation Rate & $\mathrm{r}$ & -0.009 & 0.011 & $.295 * *$ & -0.066 & -0.006 & -0.08 & 0.049 & $-.262 * *$ & -0.126 & 1 \\
\hline & $\mathrm{N}$ & 101 & 120 & 101 & 101 & 101 & 101 & 101 & 101 & 101 & 101 \\
\hline
\end{tabular}

* Correlation is significant at the 0.05 level (2-tailed).

\subsubsection{Board Structure and Performance of Commercial and Service Firms.}

Table 6 shows the correlation between board structure indicators and performance of listed commercial and service firms in Kenya. The results showed that board structure indicators had a weak correlation with performance ROA and Tobin's Q of listed commercial and service firms in Kenya. 
Table 6: Board Structure and Performance of Commercial and Service Firms.

\begin{tabular}{|c|c|c|c|c|c|c|c|c|}
\hline & & $\begin{array}{l}\text { Board } \\
\text { independe } \\
\text { nce }\end{array}$ & $\begin{array}{l}\text { Gender } \\
\text { Diversity }\end{array}$ & $\begin{array}{l}\text { Occupational } \\
\text { Expertise }\end{array}$ & Board Age & $\begin{array}{l}\text { Board } \\
\text { Size } \\
\end{array}$ & ROA & Tobin's Q \\
\hline $\begin{array}{l}\text { Board } \\
\text { independence }\end{array}$ & $\mathrm{r}$ & 1 & & & & & & \\
\hline $\begin{array}{l}\text { Gender Diversity } \\
\text { Occupational }\end{array}$ & $\mathrm{r}$ & $-.251^{*}$ & 1 & & & & & \\
\hline Expertise & $\mathrm{r}$ & $.593 * *$ & $-.359 * *$ & 1 & & & & \\
\hline Board Age & $\mathrm{r}$ & $.570 * *$ & -0.006 & $.321 * *$ & 1 & & & \\
\hline Board Size & $\mathrm{r}$ & $.720 * *$ & $-.483 * *$ & $.913 * *$ & $.407 * *$ & 1 & & \\
\hline ROA & $\mathrm{r}$ & 0.079 & $-.266^{* *}$ & $.301 * *$ & $-.242 *$ & $.235^{*}$ & 1 & \\
\hline \multirow[t]{2}{*}{ Tobin's Q } & $\mathrm{r}$ & -0.021 & $-.275^{* *}$ & $.279 * *$ & $-.295^{* *}$ & $.228^{*}$ & $.443 * *$ & 1 \\
\hline & $\mathrm{N}$ & 101 & 101 & 101 & 101 & 101 & 101 & 101 \\
\hline
\end{tabular}

*Correlation is significant at the 0.05 level (2-tailed).

\subsubsection{Board Activities and Performance of Commercial and Service Firms.}

Table 7 presents the findings of correlation analysis of board activities indicators and performance of listed commercial and service firms at NSE. The findings showed that board activities indicators had a weak correlation with both ROA and Tobin's Q of commercial and service firms listed at NSE.

Table 7: Board Activities and Performance of Commercial and Service Firms.

\begin{tabular}{|c|c|c|c|c|c|c|c|c|c|c|}
\hline & & $\begin{array}{l}\text { Board } \\
\text { Tenure } \\
\end{array}$ & $\begin{array}{l}\text { Board } \\
\text { Ownership }\end{array}$ & $\begin{array}{l}\text { Board } \\
\text { Tools }\end{array}$ & $\begin{array}{l}\text { Board } \\
\text { Meetings }\end{array}$ & $\begin{array}{l}\text { No Board } \\
\text { Committees }\end{array}$ & $\begin{array}{l}\text { Committees } \\
\text { Meetings }\end{array}$ & $\begin{array}{l}\text { Board } \\
\text { Remunerati } \\
\text { on }\end{array}$ & ROA & Tobin's Q \\
\hline $\begin{array}{l}\text { Board Tenure } \\
\text { Board } \\
\text { Ownershin }\end{array}$ & $\mathrm{r}$ & $-625 * *$ & 1 & & & & & & & \\
\hline Board Tools & $\mathrm{r}$ & -0.111 & $.202 *$ & 1 & & & & & & \\
\hline $\begin{array}{l}\text { Board Meetings } \\
\text { No. of Board }\end{array}$ & $\mathrm{r}$ & $-.288^{* *}$ & $.409^{* *}$ & -0.098 & 1 & & & & & \\
\hline $\begin{array}{l}\text { Committees } \\
\text { Committee }\end{array}$ & $\mathrm{r}$ & $-.289^{* *}$ & -0.073 & -0.034 & $-.216^{*}$ & 1 & & & & \\
\hline $\begin{array}{l}\text { Meetings } \\
\text { Board }\end{array}$ & $\mathrm{r}$ & 0.081 & -0.114 & -0.121 & -0.151 & $.748 * *$ & 1 & & & \\
\hline Remuneration & $\mathrm{r}$ & -0.111 & 0.052 & 0.153 & 0.04 & -0.123 & $-.284 * *$ & 1 & & \\
\hline ROA & $\mathrm{r}$ & -0.081 & -0.13 & $.330 * *$ & $-.465 * *$ & $.369 * *$ & $.229 *$ & 0.08 & 1 & \\
\hline Tobin's Q & $\mathrm{r}$ & -0.127 & -0.133 & $.215^{*}$ & $-.287 * *$ & $.431 * *$ & $.248^{*}$ & 0.18 & $.443^{* *}$ & 1 \\
\hline & $\mathrm{N}$ & 101 & 101 & 101 & 101 & 101 & 101 & 101 & 101 & 101 \\
\hline
\end{tabular}

* Correlation is significant at the 0.05 level (2-tailed).

\subsubsection{Financial Characteristic Variables and Performance of Commercial and Service Firms}

Table 8 presents the findings of correlation analysis between financial characteristics and performance of listed commercial and service firms at NSE. The findings showed that investments, leverage and liquidity had a weak positive correlation with both ROA and Tobin's Q of listed commercial and service firms in NSE. Only Investments had a strong correlation with Tobin's Q. 
Table 8: FC Variables and Performance of Commercial and Service Firms

\begin{tabular}{lllllll}
\hline & & Investments & Leverage & Liquidity & ROA & Tobin's Q \\
\hline Investments & $\mathrm{r}$ & 1 & & & & \\
Leverage & $\mathrm{r}$ & 0.153 & 1 & & & \\
Liquidity & $\mathrm{r}$ & $-.649^{* *}$ & -0.097 & 1 & & \\
ROA & $\mathrm{r}$ & $.428^{* *}$ & 0.128 & $.423^{* *}$ & 1 & \\
Tobin's Q & $\mathrm{r}$ & $.529^{* *}$ & 0.155 & $.317^{* *}$ & $.443^{* *}$ & 1 \\
& $\mathrm{~N}$ & 101 & 101 & 101 & 101 & 101 \\
\hline
\end{tabular}

*Correlation is significant at the 0.05 level (2-tailed).

\subsubsection{Macroeconomic Factors and Performance in Commercial and Service Sector}

Table 9 presents the correlation analysis of macroeconomic variables and performance indicators of commercial and service firms listed at NSE. The results presented showed that GDP growth rates, interest rates and inflation rates had a weak correlation with both ROA and Tobin's Q of listed commercial and service firms in Kenya.

Table 9: Macroeconomic Factors and Performance in Commercial and Service Sector

\begin{tabular}{lllllll}
\hline & & GDP & Interest Rate & Inflation Rate & ROA & Tobin's Q \\
\hline GDP Growth Rate & $\mathrm{r}$ & 1 & & & & \\
Interest Rate & $\mathrm{r}$ & -0.151 & 1 & & & \\
Inflation Rate & $\mathrm{r}$ & $-.262^{* *}$ & -0.126 & 1 & & \\
ROA & $\mathrm{r}$ & 0.053 & -0.078 & 0.09 & 1 & $.443^{* *}$ \\
Tobin's Q & $\mathrm{r}$ & 0.085 & -0.121 & -0.079 & 1 \\
& $\mathrm{~N}$ & 101 & 101 & 101 & 101 & 101 \\
\hline
\end{tabular}

** Correlation is significant at the 0.01 level (2-tailed).

\subsection{Regression Analysis}

\subsubsection{Corporate Governance Variables and Performance of Firms in Commercial \& Service Sector}

Table 10 presents the findings of effect of corporate governance variables on performance of listed firms in commercial $\&$ service sector in Kenya. The results revealed models used to link corporate governance variables to ROA (Prob>Chi2 $=0.000)$ and Tobin's $\mathrm{Q}(\mathrm{Prob}>\mathrm{Chi} 2=0.0000)$ were statistically significant which implied that corporate governance variables were significant predictor of performance of listed firms in commercial \& service sector in Kenya.

Table 10: Corporate Governance Variables and Performance of Firms in Commercial Service Sector

\begin{tabular}{|c|c|c|}
\hline & Model 1 & Model 2 \\
\hline & ROA & Tobin's Q \\
\hline Board Independence & $0.6678778 \quad(p=0.100)$ & $-1.822017 \quad(\mathrm{p}=0.147)$ \\
\hline Gender Diversity & $-0.098762 \quad(p=0.529)$ & $-0.1167565 \quad(p=0.81)$ \\
\hline Occupational Expertise & $0.0055278 \quad(\mathrm{p}=0.839)$ & $-0.0881041 \quad(\mathrm{p}=0.295)$ \\
\hline Board Age & -0.032219 & $-0.0992268 \quad(\mathbf{p}=\mathbf{0 . 0 0 2})$ \\
\hline Board Size & $-0.0066115 \quad(p=0.828)$ & $0.0986653 \quad(\mathrm{p}=0.296)$ \\
\hline Board Tenure & $-0.0879642 \quad(p=0.304)$ & $-0.6929814 \quad(\mathbf{p}=\mathbf{0 . 0 0 9})$ \\
\hline Board Ownership & $-0.7732351 \quad(\mathrm{p}=0.073)$ & $-3.588354 \quad(\mathbf{p}=\mathbf{0 . 0 0 7})$ \\
\hline Board Tools & $0.1628597 \quad(\mathbf{p}=\mathbf{0 . 0 0 5})$ & $0.3286377 \quad(\mathrm{p}=0.065)$ \\
\hline Board Meetings & $-0.1011612 \quad(\mathbf{p}=\mathbf{0 . 0 0 1})$ & $-0.0406569 \quad(\mathrm{p}=0.673)$ \\
\hline Number of board committees & $0.0078687 \quad(\mathrm{p}=0.884)$ & $0.2153269 \quad(\mathrm{p}=0.198)$ \\
\hline Committee Meetings & $0.0079789 \quad(\mathrm{p}=0.409)$ & $0.0355971 \quad(\mathrm{p}=0.234)$ \\
\hline Board Remuneration & $0.0059472 \quad(\mathrm{p}=0.824)$ & 0.0783469 \\
\hline \multirow[t]{4}{*}{ _cons } & $(\mathrm{p}=0.015)$ & $(\mathrm{p}=0.000)$ \\
\hline & Wald chi2 $(12)=81.44$ & Wald chi2 $2(12)=79.88$ \\
\hline & Prob $>$ chi $2=0.0000$ & Prob $>$ chi $2=0.0000$ \\
\hline & R-sq: $=0.4806$ & R-sq:=0.4758 \\
\hline
\end{tabular}


Board independence, occupational expertise, board tools, number of board committees, committee meetings and board remuneration were found to be positively related to ROA of listed firms in commercial \& service sector in Kenya. However, only board tools were found to be significant. Gender diversity, board age, board size, board tenure, board ownership and board meetings were found to be negatively related to ROA of listed firms in commercial \& service sector in Kenya. Board age and board meetings were found to be significantly and negatively related to ROA of listed firms in commercial \& service sector in Kenya. On the other hand, board size, board tools, number of board committees, committee meetings and board remuneration were found to be positively related to Tobin's Q of listed firms in commercial \& service sector in Kenya. Board independence, gender diversity, occupational expertise, board age, board tenure, board ownership and board meetings were found to negatively affect Tobin's Q of listed firms in commercial \& service sector in Kenya. However, board age, board tenure and board ownership had a significant effect on Tobin's Q of listed firms in commercial \& service sector in Kenya.

\subsubsection{Corporate Governance Composite and Performance of Firms in Commercial \& Service Sector}

Table 11 presents the regression results of the models fitted to test the relationship between CG composite and performance of firms (ROA and Tobin's Q) of listed Commercial \& Services firms in Kenya. Similarly, results revealed that the models fitted were statistically insignificant which implied that CG composite was insignificant predictor of performance of firms (ROA and Tobin's Q) of listed Commercial \& Service firms in Kenya.

Table 11: Model of Corporate Governance Composite and Performance of Firms in Commercial \& Service Sector

\begin{tabular}{|l|l|l|}
\hline & Model 1 & Model 2 \\
\hline & ROA & Tobin's Q \\
\hline CG & $0.00000571(\mathrm{P}=0.181)$ & $-0.00000669(\mathrm{p}=0.592)$ \\
\hline Cons & $0.0795399 \quad(\mathrm{P}=0.404)$ & $1.788119 \quad(\mathrm{p}=0.000)$ \\
\hline & \multicolumn{1}{|c|}{ Wald chi2 $(1)=0.29$} \\
\hline & Wald chi2 $(1)=1.79$ & Prob>chi2 $=0.5917$ \\
\hline & Prob>chi2=0.1808 & R-sq $=0.0035$ \\
\hline & R-sq:=0.0223 & \\
\hline
\end{tabular}

\subsubsection{Summary of the Intervening Effect of Financial Characteristics in Commercial and Service sector}

Table 12 presents the summary of the intervening effect of financial characteristics on the relationship between corporate governance and performance of listed firms in commercial \& service sector. The findings showed that none of the financial characteristic variables achieved the four steps of intervention as suggested by Baron and Kenny (1986) hence the study concluded that investment, leverage and liquidity insignificantly intervened the relationship between corporate governance and performance of listed firms in commercial \& service sector in Kenya.

Table 12: Summary of the Intervening Effect of Financial Characteristics in Commercial \& Service Sector

\begin{tabular}{|c|c|c|c|c|}
\hline Steps & IV & DV & Result & Intervention \\
\hline 1 & CG & ROA & Insignificant & Not Achieved \\
\hline \multirow[t]{2}{*}{2} & CG & Investment & insignificant & Not Achieved \\
\hline & & Liquidity & insignificant & Not Achieved \\
\hline \multirow[t]{4}{*}{3} & Investment & ROA & insignificant & Not Achieved \\
\hline & & Tobin's Q & significant & Achieved \\
\hline & Liquidity & ROA & significant & Achieved \\
\hline & & Tobin's Q & significant & Achieved \\
\hline \multirow[t]{4}{*}{4} & CG & ROA & Insignificant & Not Achieved \\
\hline & & Tobin's Q & Insignificant & Not Achieved \\
\hline & Investment & ROA & insignificant & Not Achieved \\
\hline & & Tobin's Q & significant & Achieved \\
\hline
\end{tabular}

Source: Author, 2018 


\subsubsection{Moderating effect of Macroeconomic Variables in Commercial \& Service Sector}

This section presents the findings of sectoral model fitting for moderating effect of macroeconomic variables on the relationship between corporate governance variables and performance of commercial \& services firms listed at NSE in Kenya.

Table 12: Step One: Models Fitting for Moderating effect of Macroeconomic Factors in Commercial \& Service Sector

\begin{tabular}{|l|l|l|}
\hline & Model 1 & Model 2 \\
\hline & ROA & Tobin's Q \\
\hline CG & $0.00000553(\mathrm{P}=0.182)$ & $-0.00000871 \quad(\mathrm{P}=0.482)$ \\
\hline GDP Growth Rate & $0.0085053 \quad(\mathrm{P}=0.527)$ & $0.0202893 \quad(\mathrm{P}=0.581)$ \\
\hline Interest Rate & $-0.0069949(\mathrm{P}=0.554)$ & $-0.0555139 \quad(\mathrm{P}=0.087)$ \\
\hline Inflation Rate & $0.0068003 \quad(\mathrm{P}=0.409)$ & $-0.0297795 \quad(\mathrm{P}=0.187)$ \\
\hline cons & $0.0964341 \quad(\mathrm{P}=0.683)$ & $2.773831 \quad(\mathrm{P}=0.000)$ \\
\hline & & \multicolumn{1}{|c|}{ Wald chi2 $(4)=5.97$} \\
\hline & Wald chi2 $(4)=3.40$ & Prob> chi2 $=0.2014$ \\
\hline & Prob>chi2 $=0.4938$ & R-sq:=0.0213 \\
\hline & R-sq: $=0.0406$ & \\
\hline
\end{tabular}

Table 13: Step Two: Models Fitting for Moderating effect of Macroeconomic Variables in Commercial \& Service Sector

\begin{tabular}{|l|l|l|}
\hline & Model 1 & Model 2 \\
\hline & ROA & Tobin's Q \\
\hline CG & $0.0000484 \quad(\mathrm{P}=0.406)$ & $-0.0000797 \quad(\mathrm{P}=0.628)$ \\
\hline GDP Growth Rate & $0.0142956 \quad(\mathrm{P}=0.307)$ & $0.0188491 \quad(\mathrm{P}=0.632)$ \\
\hline Interest Rate & $-0.0143149 \quad(\mathrm{P}=0.238)$ & $-0.0687618 \quad(\mathrm{P}=0.044)$ \\
\hline Inflation Rate & $0.0108396 \quad(\mathrm{P}=0.207)$ & $-0.0343803 \quad(\mathrm{P}=0.155)$ \\
\hline IT1 & $-0.0000126 \quad(\mathrm{P}=0.115)$ & $-0.00000253 \quad(\mathrm{P}=0.912)$ \\
\hline IT2 & $0.00000651 \quad(\mathbf{P}=\mathbf{0 . 0 1 7})$ & $0.0000057 \quad(\mathrm{P}=0.466)$ \\
\hline IT3 & $-0.00000953(\mathrm{P}=\mathbf{0 . 0 2 8})$ & $0.000000424 \quad(\mathrm{P}=0.973)$ \\
\hline Cons & $0.1266062 \quad(\mathrm{P}=0.597)$ & $2.98536 \quad(\mathrm{P}=0.000)$ \\
\hline & & \multicolumn{1}{|l|}{} \\
\hline & Wald chi2 $(7)=10.62$ & Wald chi2(7)= 7.79 \\
\hline & Prob>chi2= 0.1562 & Prob $>$ chi2 $=0.3518$ \\
\hline & R-sq:= $\quad 0.0537$ & 0.0348 \\
\hline
\end{tabular}

Table 12 and Table 13 show that macroeconomic factors increased the explanatory power of corporate governance on performance of listed commercial \& service firms. The results revealed that R-squared increased from 0.0406 to 0.0537 in the first model while increased from 0.0213 to 0.0348 in the second model with the inclusion of the interaction variables. Inflation rate and interest rate significantly moderated the relationship between corporate governance and ROA of listed commercial \& service firms while the moderating effects of GDP growth rate was insignificant. None of the macroeconomic factors had significant moderating effect on the relationship between corporate governance and Tobin's Q of listed commercial \& service firms in Kenya

\subsubsection{Joint Effect of Corporate Governance, Financial Characteristics, Macroeconomic Factors on Performance} of Commercial \& Service Firms

This section presents the findings on effect of corporate governance, financial characteristics, and macroeconomic factors on performance of listed commercial \& service firms in Kenya. During the period of the study NSE had listed 10 commercial \& service firms hence the data for these firms were adequate in conducting analysis. 
Table 14: Joint Effect of CG, FC, Macroeconomic Factors on Performance of Commercial \& Service Firms

\begin{tabular}{|c|c|c|}
\hline & Model 1 & Model 2 \\
\hline & ROA & Tobin's Q \\
\hline $\mathrm{CG}$ & $0.00000023 \quad(\mathrm{p}=0.431)$ & $-0.00000019 \quad(p=0.080)$ \\
\hline Investments & $0.159 \quad(p=0.246)$ & $(\mathrm{p}=0.000)$ \\
\hline Leverage & $-0.004 \quad(p=0.571)$ & $(p=0.494)$ \\
\hline Liquidity & $0.886 \quad(p=0.000)$ & $(\mathrm{p}=0.729)$ \\
\hline GDP Growth rate & $(\mathrm{p}=0.634)$ & $(\mathrm{p}=0.218)$ \\
\hline Interest Rate & $-0.024 \quad(p=0.026)$ & $(\mathrm{p}=0.230)$ \\
\hline Inflation Rate & $-0.001 \quad(p=0.853)$ & $(\mathrm{p}=0.434)$ \\
\hline _Cons & $(\mathrm{p}=0.064)$ & $(\mathrm{p}=0.000)$ \\
\hline & Wald chi2(7)=16.700 & Wald chi2 $2(7)=6.898$ \\
\hline & Prob $>$ chi $2=0.000$ & Prob $>$ chi $2=0.000$ \\
\hline & R-sq:within $=0.524$ & R-sq: within $=0.292$ \\
\hline
\end{tabular}

Table 15 shows both model 1 linking CG, FC, macroeconomic factors and ROA (Prob>chi2=0.000), and Model 2 linking CG, FC, macroeconomic variables and Tobin's Q (Prob>chi2 $=0.000$ ) were statistically significant. These findings implied that $\mathrm{CG}, \mathrm{FC}$, macroeconomic factors were good predictors of listed commercial \& service firms performance. The research findings revealed that Liquidity $(\beta=0.886, p=0.000)$ and Interest Rate $(\beta=-0.024, p=0.026)$ significantly affect ROA while $C G(\beta=0.00000023, p=0.431)$, Investments $(\beta=0.159, p=0.246)$, Leverage $(\beta=-0.004$, $\mathrm{p}=0.571)$, GDP Growth rate $(\beta=-0.006, \mathrm{p}=0.634)$ and Inflation Rate $(\beta=-0.001, \mathrm{p}=0.853)$ had an insignificant effect on ROA of listed commercial \& service firms. The results further revealed that only firm Investments $(\beta=-2.629, p=0.000)$ was significantly related to Tobin's $Q$ of listed commercial \& service firms in Kenya. CG $(\beta=-0.00000019, p=0.080)$, Leverage $(\beta=-0.020, p=0.494)$, Liquidity $(\beta=-0.135, p=0.729)$, GDP Growth rate $(\beta=0.056, p=0.218)$, Interest Rate $(\beta=-$ $0.048, \mathrm{p}=0.230)$ and Inflation Rate $(\beta=-0.022, \mathrm{p}=0.434)$ were found to have insignificant effects on Tobin's $\mathrm{Q}$ of listed commercial \& service firms.

\section{Model 1}

$\mathrm{FP}_{\mathrm{it}}(\mathrm{ROA})=0.388+0.00000023 \mathrm{CG}_{\mathrm{it}}+0.159 \mathrm{IN}_{\mathrm{it}-1}+-0.004 \mathrm{LE}_{\mathrm{it}-1}+0.886 \mathrm{LI}_{\mathrm{it}-1}+-0.006 \mathrm{GDP}_{\mathrm{it}-1}+-0.024 \mathrm{INR}_{\mathrm{it}-1}+-$ $0.001 \mathrm{IFR}_{\mathrm{it}-1}+\mathrm{c}_{\mathrm{i}}+\dot{\varepsilon}_{\mathrm{it}}$

\section{Model 2}

$\mathrm{FP}_{\text {it }}\left(\right.$ Tobin's Q) $=3.947+-0.00000019 \mathrm{CG}_{\mathrm{it}}+-2.629 \mathrm{IN}_{\mathrm{it}-1}+-0.020 \mathrm{LE}_{\mathrm{it}-1}+-0.135 \mathrm{LI}_{\mathrm{it}-1}+--0.056 \mathrm{GDP}_{\mathrm{it}-1}+-0.048 \mathrm{INR}_{\mathrm{it}-}$ ${ }_{1}+-0.022$ IFR $_{\text {it }-1}+c_{i}+\dot{\varepsilon}_{\text {it }}$

Where;

$\mathrm{CG}=$ Corporate Governance

IN = Firm Investments

LE $=$ Firm Leverage

LI= Firm Liquidity

GDP $=$ GDP growth Rate

INR $=$ Interest Rate

IFR= Inflation Rate

$\varepsilon=$ Error Term

\subsection{Conclusion}

The study concluded that commercial and service listed firms in Kenya adopted corporate governance practices as part of the requirements of the regulating authority which had no impact on the specific firm's performance. The study established that most of the corporate governance practices adopted by commercial and service listed firms in Kenya had an insignificant effect on the performance of listed firms. The study concluded that commercial and service listed firms in Kenya strengthened their corporate governance due to poor performance, further the study concluded that 
corporate governance practices used by commercial and service listed firms failed to impact on performance. The study also concluded that listed commercial and service firms in Kenya continued to record poor performance despite corporate governance investments. The study finally concluded that commercial and service listed firms that focused on enhancing their corporate governance, financial characteristics and operated in favorable macroeconomic environment were likely to increase their performance since jointly; corporate governance, financial characteristics and favorable macroeconomic conditions were found to account for the highest performance in both ROA and Tobin's Q of the listed firms in Kenya.

\subsection{Recommendations}

Based on the findings, the study recommended that commercial and service listed firms should revisit their corporate governance practices to ensure that leverage on board structures and board activities that improve performance while obsolete corporate governance practices should be eradicated. The shareholders of commercial and service listed firms may adopt the findings of this study to restructure their corporate governance by implementing board structures and board activities that will improve performance of their firms or realign the corporate governance practices to make them more effective. The stakeholders may also use the findings of this study to open inquiry on effectiveness of corporate governance in their respective firms for future improvement. Based on these findings, it was recommended that management of commercial and service listed firms should restructure and optimize their financial characteristics to achieve higher level performance of their firms.

\section{References}

Abu-Tapanje, D.M. (2007). Good corporate governance mechanism and firms' operating and financial performance: insight from the perspective of Jordanian industrial companies. Academy of Management Review, 12 (3), 231279.

Aduda, J., Chogii, R. \& Magutu, P. O. (2013). An empirical test of competing corporate governance theories on Performance of firms listed at the Nairobi securities exchange. European Scientific Journal, IX (13), 107-137

Aghouei, M. V. \& Moradi, M. (2015).A study of the relationship of firm characteristics and corporate governance with the difference between declared and final taxes in Iran. Mediterranean Journal of Social Sciences, 6(4), 488

Badriyah, N., Sari, N. S. \& Basri, Y. M. (2015). The effect of corporate governance and firm characteristics on Performance of firms and risk management as an intervening variable. Procedia Economics and Finance 31(20125), 868-875

Baldwin, C, Bagley, C., \& Quinn, J. (2003).M\&A legal context: Basic framework for corporate governance. Harvard Business School Press, 9-803-200

Bantel , K. A. \& Jackson,S. E. (1989). Top management and innovations in banking: does the composition of the top team make a difference? Strategic Management Journal, 10,107-124

Baysinger, B. \& Butler, H. (1985). Corporate governance and the board of directors: Performance effects of changes in board composition. Journal of Law, Economics and Organizations, 1(1), 101-124

Boussouara, M. \& Deakins, D (2000). Market based learning, entrepreneurship and the high technology small firm. International Journal of Entrepreneurial Bahaviour and Research, 5(4), 204-223

Brickley, J.A., Lease, D. \& Smith, R.C.W. (1988).Ownership structure and voting on anti-takeover amendments. Journal of Financial Economics, 20(1), 267-291

Bryaman, A. \& Cramer, D. (1997). Quantitative Data Analysis with SPSS for Windows: A guide for Social Scientists. London: Routledge

Buvanendra, S., Sridharan, P. \& Thiyagarajan, S. (2017). Firm characteristics, corporate governance and capital structure adjustments: a comparative study of listed firms in Sri Lanka and India. Journal of IIMB Management Review, 29(4), 245-258

Carpenter, M., Geletkanycz, M. \& Sanders, W. (2004). Upper echelons research revisited: Antecedents, elements, and consequences of top management team composition. Journal of Management, 30(6), 747-778

Carter, D., Simkins, B. \& Simpson, W. (2003).Corporate governance, board diversity, and firm value. The Financial Review, 38, 33-53

Dalton, D., Daily, C., Ellstrand, A. \& Johnson, J. (1998) Meta-analytic reviews of board composition, leadership structure, and financial performance. Strategic Management Journal, 19, 269-290

Deloof, M. (2003). Does working capital management affect profitability of Belgium firms? Journal of Business finance and Accounting, 30 (3-4), 573-588. 
Faizul, H. \& Thankom , G. A. (2016). Corporate governance and financial performance; an emerging economy perspective. Journal of Investment, Management and Innovations, 13(3).228-236

Gachoki S. \& Rotich, G. (2013). Influence of corporate governance on the performance of public organizations in Kenya (a case of Kenya ports authority). Research Journal of Finance and Accounting. 4 (6), 205-215

Gallagher, M. (2011). The effect of inflation of housing prices from http://homeguides.sfgate.com/effect-inflationhousing-prices-2161.html

Hillier, D., Jaffe, J., Jordan, B., Ross, S., \& Westerfield, R. (2010). Corporate finance, $1^{\text {st }}$ European Edition, McGrawHill Edition

Hillman, A.J. \& Keim, G. D. (2001).Shareholder value, stakeholder management and social issues. What's the bottom line? Journal of Strategic Management, 22,125-139

Hillman, A.J., Canella, A. A. \& Paetzold, R. L. (2000). The resource dependency role of corporate directors: strategic adaptation of board composition in response to environmental change. Journal of Management Studies, 37(2), 235-255

Ibe, H. C. A., Ugwuanyi, G. O. \& Okanya, O. C. (2017). Effects of corporate governance mechanisms on financial performance of insurance companies in Nigeria, Journal of Finance and Accounting, 5(3),93-103

Iraya, C., Mwangi, M. \& Muchoki, G. W. (2015). The effect of corporate governance practices on earnings management of companies listed at the Nairobi securities exchange. European Scientific Journal, 11 (1), 1857 $-7881$

Jacob, S. (2015). Effects of macroeconomic forces on corporate governance performance of Indian companies: an exploratory study. International Journal of Marketing, Financial Services \& Management Research.4 (3), 149-176

Jensen, M. (1986).Agency Costs of Free Cash Flow, Corporate Finance, and Takeovers. American Economic Review, 76(2) 323-329

Jensen, M. C. \& Murphy, K. J. (2010). CEO incentives-it is not how much you pay, but how. Journal of Applied Corporate Finance, 22(1), 64-76

Johnson, J.L., Daily, C.M. and Ellstrand, A.E. (1996). Boards of directors: a review of research agenda. Journal of Management, 22(3), 409-438

Jones, T. M., \&Felps, W. (2013). Shareholder wealth maximization and social welfare: A utilitarian critique. Business Ethics Quarterly, 23(2), 207-238

Khanchel, I. (2007). Corporate governance: measurement and determinant analysis. Managerial Auditing Journal, 22 (8), 740-760

Klein, A .(2002). Audit committee, board of director characteristics, and earnings management. Journal of Finance and Economics. 33(3), 374-440

Koori M. J. (2014). Financial flexibility and corporate investment among non-financial companies listed on Nairobi Securities Exchange, Kenya. (PhD Thesis, Kenyatta University)

Lekaram , V. (2014). Relationship of corporate governance and financial performance of manufacturing firms listed in the Nairobi securities exchange. International Journal of Business and Commerce, 3, (12), 30-57

Liow, K.H., Ibrahim, M.F. \& Huang, Q. (2006). Macroeconomic risk influences in the property stock market. Journal of property investment and finance, 24(4).

Lipton, J. \& Lorsch, J. (1992). A modest proposal for improved corporate governance, Business Laywer, 48(1), 59-77 management policies on firm's profitability and value: evidence from Iranian

Mathew H., Paul H., Kamel M. \& Cherif, G. (2010). Short-term versus long-term impact of managers: evidence from the football industry. British Journal of Management, 21, 571-589

Michelberger, K. J. (2017). Impact of corporate governance of firm performance and total shareholder return of German listed companies. (PhD Thesis, University of Lativa)

Mudida, R. \& Ngene, G. (2010).Financial management, Nairobi: Focus Publishers Ltd

Mulili, B. M. \& Wong, P. (2011). Corporate governance practices in developing countries: The case for Kenya. International Journal of Business Administration, 2 (1), 14-27

Nandi, S. \& Ghosh, S. K. (2012). Corporate governance attributes, firm characteristics and the level of corporate disclosure: evidence from the Indian listed firms. Decision Science Letters, 2, 45-58

Okioga, C. K. (2013). The contribution of good corporate governance practices on the flow of investor into Nairobi securities exchange. International Journal of Current Research,5(8), 2391-2398

Ombayo, J. O. (2011). The effect of corporate governance on a firm's financial performance: a case study of companies listed on the Nairobi Stock Exchange (PhD Thesis, University of Nairobi)

Ondigo, H. O. (2016). Corporate governance, risk management, firm characteristics and financial performance of commercial bank in Kenya. (PhD Thesis, University of Nairobi) 
Ongore, V. O. \& K'Obonyo, P. O. (2011). Effects of selected corporate governance characteristics on Performance of firms: empirical evidence from Kenya. International Journal of Economics and Financial Issues, 1(3), 99-122

Pfeffer, J. \& Salancik, G. R. (1978), The External Control of Organizations: A Resource Dependence Perspective, Harper \& Row, New York

Posner, R. A. (1983). The economics of justice. Harvard University Press

Rambo, C. M. (2013). Influence of the capital markets authority's corporate governance guidelines on financial performance of commercial banks in Kenya. The International Journal of Business and Finance Research, 7 (3), 7-91

Ribeiro, A., Cerqueira, A., \& Brandão, E. (2015).The determinants of effective tax rates: firms' characteristics and corporate governance: Working Paper, FEP- $\quad$ UP, School of Economics and Management, University of Porto

Rose, C. (2007). Does female board representation influence firm performance? The Danish evidence, corporate governance. An International Review, 15(2), 404-413

Ruigrok, W., Peck, S. \& Tacheva, S. (2007). Nationality and gender diversity on Swiss corporate boards," Corporate Governance, 15 (4), 546-557

Santoni, G. J. (1986). The effects of inflation on commercial banks: Federal Reserve

Sharp P., Ainslie T., Hamphil A., Hobsin S., Merrman C., Ong P and Roche J. (2005) Monitoring. http://www.practicebasedlearning.org/resources/materials/docs/Brooks\%20final.pdf

Souha, S. B., \& Anis, J. (2016). Corporate governance and firm characteristics as explanatory factors of shareholder activism: validation through the French context. Cogent Economics \& Finance, 4(1), 1-19

Tricker, R. B., \& Tricker, R. I. (2015).Corporate governance: Principles, policies, and practices. Oxford University Press, USA

Vahid, T. K., Mohsen, A. K. \& Mohammadreza, E. (2012). The impact of working capital

Van-Ness, R. K., Miesing, P., \& Kang, J. (2010).Board of director composition and financial performance in a sarbanes-oxley world.Academy of Business and Economics Journal, 10(5), 56-74

Vo, D. H., \& Nguyen, T. M. (2014). The impact of corporate governance on performance of firms: Empirical study in Vietnam. International Journal of Economics and Finance, 6(6), 1-13

Wakaisuka, J. I.,Aduda J., Wainaina, G., Iraya, M. \& Ntim C. G. (2016). Corporate governance, firm characteristics, external environment and performance of financial institutions in Uganda. A review of literature. Cogent Business \& Management, 3(1),1-14

Wang, C. J. (2014). The impact of macroeconomic and corporate governance factors on firm value of Taiwanese green technology industry: a consideration of differential slope. International Journal of Economics and Finance, 6 (7),1916- 9728

Waweru, N. M. \& Riro, G. K. (2013).Corporate governance, firm characteristics and earnings management in an emerging economy.JAMAR.11(1)

Windsor, D., \& Boatright, J. R. (2010).Shareholder wealth maximization. Finance ethics: Critical issues in theory and practice, $437-455$

Wright, P., Ferris, S., Sarin, A. \& Awasthi, V. (1996). Impact of corporate insider, block holder, and institutional equity ownership on firm risk taking. Academy of Management Journal, 39,441-463 